\title{
Interference of Square Footings on Geocell Reinforced Clay Bed: Experimental and Numerical Studies
}

\author{
Akash Gupta, Gulshan K. Lakshman, T. G. Sitharam \\ Indian Institute of Science \\ Bangalore, India \\ akashgupta2424@gmail.com ; lakshman181293@gmail.com; sitharam@iisc.ac.in
}

\begin{abstract}
When the building foundations are to be constructed close to each other, either due to less availability of space for the construction or due to plot boundaries force the designer to place the footings nearby each other. When footings are placed close to each other with similar soil conditions, the ultimate or allowable bearing capacity of footings may change due to the interference effect of the failure surface in the soil. The Interference of the two closely spaced footings is a phenomenon that is observed when two footings are closely spaced. Current study illustrates the effect of interference on closely spaced square footings in geocell-reinforced clay beds using model tank experiment and 3-Dimensional numerical modeling simulations. Experimental results suggest that with increase in the clear spacing interference decreases and after $2 \boldsymbol{B}$ spacing between the footings the interference effects are almost zero ( $\mathrm{B}=$ Width of the footing). The interference effect is quantified as Interference Factor, IF and is defined as ratio of ultimate bearing pressure of an interfering footing to that of an isolated footing. Maximum Interference Factor of about 1.5 is observed when spacing between footings/width of footing ratio was 0.5 . whereas in case of un-reinforced clay, and in the case of geo-cell reinforced clay, ultimate bearing pressure was found to be about 4 times than un-reinforced isolated footing. Due to applied stress, there is increase in confinement pressure below the interfering footings at shallow depths, which in turn is due to the interaction between the failure zones of interfering footings that which increases bearing capacity. To this end, FLAC 3D (Fast Lagrangian Analysis of Continua in 3 Dimensions) models were developed and numerical simulations have been carried out with detailed parametric analysis- after validating results with the model experiments.
\end{abstract}

Keywords: Interference Factor, Spacing between Footings, Failure Zone, Bearing Capacity, Confinement Pressure, Geocell.

\section{Introduction}

Interference is a phenomenon that is observed when two footings are placed closed to each other. Interference has a significant effect on both allowable bearing capacity and ultimate bearing capacity, which is turn, is attributed to increase in confinement pressure between the adjacent footings. In the recent past, topic of interference between footings has attracted attentions of many researchers who have demonstrated the effects of interference of footings on sand both experimentally [1] and numerically [2]. However, till now there are no studies on interference of footings on clay reinforced clay.

In current study interference of two closely spaced footings on geocell reinforced clay is illustrated both experimentally and numerically. Soil reinforcement has been proven to increase the capacity of soil and there are rapid advances in soil reinforcement. There are numerous experimental and numerical investigations to depict improvement of ultimate bearing capacity of shallow foundations on reinforced clay with geogrids [3-4]. However, topic of interference effect of footings on geocell reinforced clay has remained untouched. In this study, it is illustrated in details both experimentally and numerically the effect of interference of footings laying on geocell reinforced clay. Numerical study is done using finite difference code FLAC 3D [Fast Lagrangian Analysis of Continua in 3 Dimensions Itasca 2008] with an appropriate constitutive model [5]. The soil is modeled as elasto-plastic material with Mohr-Coulomb yield criterion. Effects of interference on allowable bearing stress is also studied and it is observed that, due to interference both in unreinforced and geocell-reinforced clay, there is significant improvement in allowable bearing stress corresponding to small deformation or initial stiffness in the Load v/s deformation curve has been observed due to interference in both unreinforced and geocell-reinforced clays. 


\section{Experimental Procedure}

In this study 2 sets of 5 plate load (first set for un-reinforced and second set for Geocell-reinforced) tests (total 10 tests) were performed on clay bed. These 10 plate load tests cover variation of pacing between footings/width of the footing $(S / B)$ ranging from: $\mathbf{0 , 0 . 5}, 1 \& 2$, and one isolated footing. The model tests were conducted in a rectangular tank of $0.9 \mathrm{~m}$ length $\times 0.9 \mathrm{~m}$ width and $0.6 \mathrm{~m}$ depth. The size of the square footing considered was $100 \mathrm{~mm} \times 100 \mathrm{~mm}$ square plate of $20 \mathrm{~mm}$ thick made up of mild steel. To simulate rough footing, bottom of the footing was attached with coarse sand paper.

Reinforcement with geocell (properties of geocell is presented in Table 3) was placed for the full width of the tank. Small gaps between tank edge and geocell were provided to avoid boundary condition. Depth of geocell placement was .5B. The geometry of the test configuration is shown in fig. 1. Four Linear Variable Differential Transducers (LVDTs) were used to measure the settlement of the footings. To measure the applied loads on the footings two load cells of 2 tonne capacity were used which were placed between the hydraulic jack and footing with ball bearing arrangement. Dimensions of the footings and that of the test tank was selected such that failure wedge of the footing would extend within the tank size as illustrated by Selig and Mckee in their study [6]. They found that failure wedge extends maximum to the distance 2 to $2.5 \boldsymbol{B}$ from an edge the footing and up to depth of $1.1 \boldsymbol{B}$. For larger spacing between the footings, distance between centre of the footing and tank's edge was about $2.5 \boldsymbol{B}$, width of the footing and the tank's height was $6 \boldsymbol{B}$. Photographic view of geometry of two closely spaced square footings is shown in fig. 2.

\subsection{Preparation of Clay Bed}

Clay was first pulverized and then mixed with predetermined quantity of water. Then it was placed in an air tight container for 72 hours to allow uniform distribution of moisture. Soil was then uniformly compacted using plate compactor in the layer of $5 \mathrm{~cm}$ thick layer to achieve desired foundation bed's height. Uniform test condition was maintained by controlling the compaction effort and moisture content in the clay bed. Undisturbed samples were collected from different locations of the test bed to obtain degree of saturation, unit weight and undrained shear strength. Table 2 represents the properties of clay bed maintained for this study.

For geocell reinforced test series, the reinforcement (geocell) was placed along the full width of the tank with small gap from the edges to avoid boundary conditions. In present study geocell is placed at the depth (u) of 0.5 B. A good quality sand with relative density $55 \%$ is used to fill the geocell pocket.

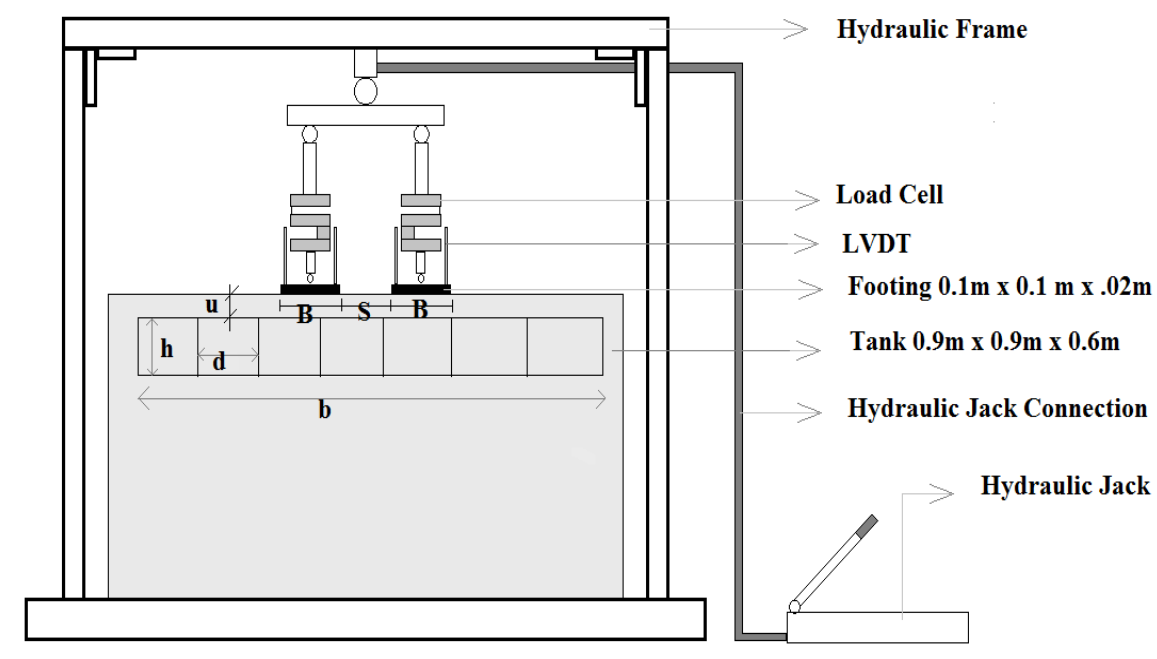

Fig. 1: Experimental setup- schematic view. 


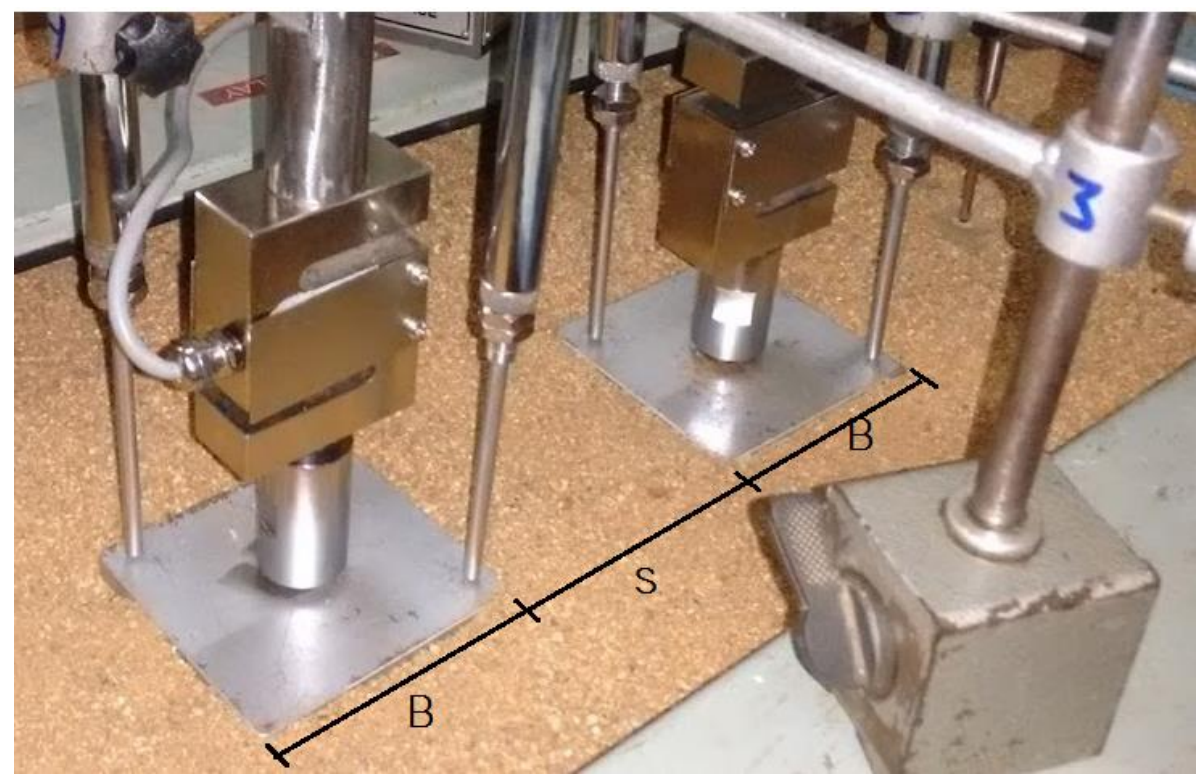

Fig. 2: Experimental setup - photographic view.

\subsection{Properties of Clay}

Clay used in this study is collected from North Bangalore region in the Bangalore city, Karnataka, India. It was observed that more than $50 \%$ of the soil fraction is finer than $0.075 \mathrm{~mm}$, the soil is thus classified was per Unified Classification system (ASTM D2487-11). Different properties of the clay used are presented in the table 1. The clay was classified as clay with low plasticity (CL).

Table 1: Properties of clay.

\begin{tabular}{|c|c|}
\hline Properties & Values \\
\hline Specific Gravity, $\mathrm{G}$ & 2.65 \\
\hline Unified soil classification & $\mathrm{CL}$ \\
\hline Maximum dry density $\left(\mathrm{kN} / \mathrm{m}^{3}\right)$ & 18.4 \\
\hline Optimum moisture content $(\%)$ & 13.5 \\
\hline Liquid limit $(\%)$ & 41 \\
\hline Plastic limit (\%) & 16 \\
\hline Shrinkage limit $(\%)$ & 14 \\
\hline Plasticity Index & 25 \\
\hline Activity & 1.53 \\
\hline Coefficient of consolidation, $\mathrm{C}_{\mathrm{v}}\left(\mathrm{m}^{2} / \mathrm{year}\right)$ & 8.1 \\
\hline Pre-consolidation pressure, $\mathrm{p}^{\prime} \mathrm{c}(\mathrm{kPa})$ & 100 \\
\hline Compression Index, $\mathrm{C}_{\mathrm{c}}$ & 0.5 \\
\hline Swelling Index, $\mathrm{C}_{\mathrm{s}}$ & 0.2 \\
\hline Coefficient of permeability, $\mathrm{k}$ & $3.24 \times 10^{-7} \mathrm{~m} / \mathrm{s}$ \\
\hline
\end{tabular}


Table 3: Properties of Neoweb Geocell.

\begin{tabular}{|c|c|}
\hline Parameters & Values \\
\hline Aspect Ratio & 0.62 \\
\hline Equivalent cell Diameter $(\mathrm{mm})$ & 223 \\
\hline No. of Cells/m & 22 \\
\hline Strip Thickness $(\mathrm{mm})$ & 1.52 \\
\hline Cell Depth $(\mathrm{mm})$ & 150 \\
\hline Cell seam strength $(\mathrm{N})$ & $2140( \pm 5 \%)$ \\
\hline Density $\left(\mathrm{g} / \mathrm{cm}^{3}\right)$ & $0.94( \pm 5 \%)$ \\
\hline Tensile Strength $(\mathrm{kN} / \mathrm{m})$ & 20 \\
\hline
\end{tabular}

\subsection{Experiment Results}

Load v/s settlement curve is presented in fig. 3. Both footing settlement(s) and clear spacing (S) is normalized with width of the footing (B) to represent them in non-dimensional form. Isolated footing is the condition where single footing was used, and interfering footing with clear spacing between footings viz $\mathrm{S} / \mathrm{B}=0,0.5,1,2$ are used. To ascertain the consistency of the test results each test was repeated at least thrice. When clear spacing between the interfering footings is increased from 0 to 2, it was noticed that effect of interference reduced. Ultimate bearing capacity for isolated footing and interfering footings with $\mathrm{S} / \mathrm{B}=2$ was approximately equal, which explains, there was no interference between the adjacent footings for $\mathrm{S} / \mathrm{B}=2$.

\subsection{Comparison of the Performance of Geocell}

Use of geocell has improved the load carrying capacity significantly. Ultimate bearing capacity in isolated footing for Geocell reinforced clay bed improved about 3.5 times as compared to unreinforced bed whereas about 3 times for interfering footing with spacing equals $0.5 \mathrm{~B}$. Failure for unreinforced case occurred at low settlement of about $2.5 \%$ it is observed that footing is unable to resist additional pressure whereas when geocell was applied, there was significant improvement in the slope at initial settlement. At any particular s/B (\%) higher bearing stress was observed in case of geocell reinforced as well as for interfering footing with clear spacing/width $(\mathrm{S} / \mathrm{B})=0.5$ which shows that there exists interference in both unreinforced as well as in geocell reinforced clay bed.

\subsection{Variation of Interference Factor, $I_{F}$ with spacing between footings}

Interference factor has been defined as

$$
I_{F}=\frac{\text { ultimate load carrying capacity of interfering footing }}{\text { ultimate load carrying capacity of isolated footing }}
$$

In addition to this, for convenience suffixes unr and Gecell to $\boldsymbol{I}_{\boldsymbol{F}}$ is added to represent interference factor for unreinforced case and geocell reinforced case respectively viz. $\boldsymbol{I}_{F-\text { unr }} \& \boldsymbol{I}_{F-\text { Geocell. }}$ 


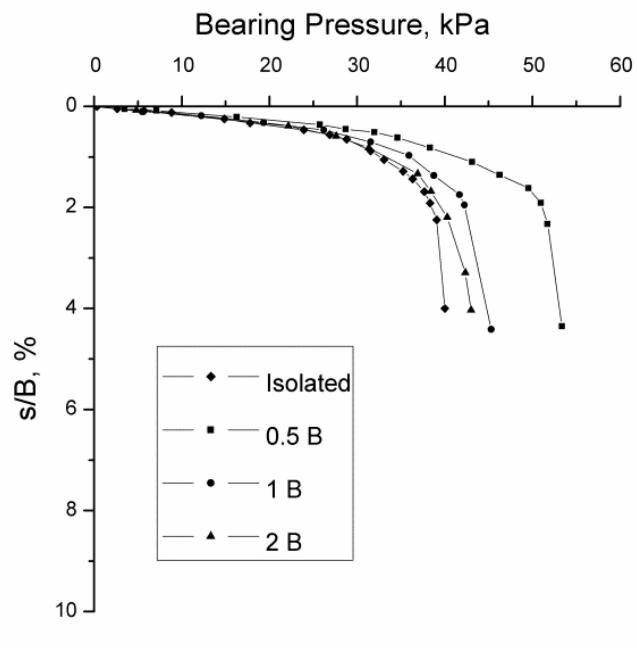

(a)

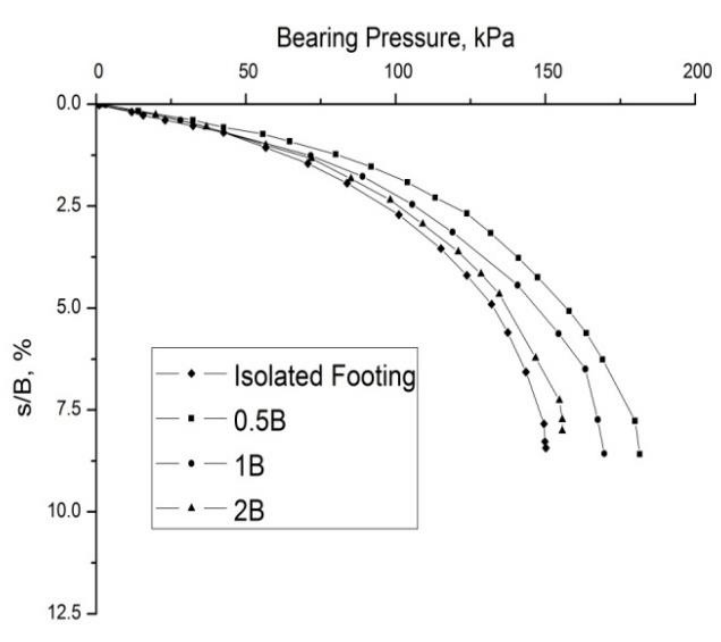

(b)

Fig. 3: a-b Variation of Bearing Pressure with footing settlement for

(a) Unreinforced clay; (b) Geocell reinforced.

As the findings suggest that there is significant increase in the confining pressure for $\mathrm{S} / \mathrm{B}=0.5$ and low confining pressure for $\boldsymbol{S} / \boldsymbol{B}=1 \& 2$, this explains why there is significant improvement in bearing capacity $\left(\boldsymbol{I}_{\boldsymbol{F}}=1.2\right)$ for $\boldsymbol{S} / \boldsymbol{B}=0.5$ and negligible improvement $\left(\boldsymbol{I}_{\boldsymbol{F}}=1.03\right)$ for $\boldsymbol{S} / \boldsymbol{B}=2$.

\section{Numerical Studies}

FLAC 3D finite difference code was used to simulate the interference of footings corresponding to the model studies carried out and also to determine ultimate bearing pressure.In this study FLAC 3D, finite difference code was used to simulate the interference of footings corresponding to the model studies carried out and also to determine ultimate bearing pressure. In this study series of 3D simulations of model footings in the test tanks were run to study the influence on interference due to variation in angle of shearing resistance and geometric variation of footings. The size of model was same as that of the dimension of the tank used for experiments i.e. $0.9 \mathrm{~m} \times 0.9 \mathrm{~m} \times 0.6 \mathrm{~m}$ and this was discretized into 22400 zones. Size of the square footing is identical to that used in experiment i.e. $100 \mathrm{~mm}$. Displacements along bottom was restrained in both horizontal and vertical whereas displacement along the sides of the tank was restrained in horizontal directions. Fig. 4a-b shows the selected geometries and discretized zones of the selected model for numerical studies.To simulate the rough footings, nodes representing the footings were fixed in both the directions constrained in horizontal direction. Elastic-perfectly plastic Mohr-Coulomb criterion was selected as constitutive model of the soil mass.

Geocell material was created using geogrid element available in FLAC 3D. The geogrid elements is used to create flexible membranes (example: geotextile, geocell) whose shear interaction with the soil are important. Magnitude of chosen velocity in the current study is $2 * 10^{-7} \mathrm{~m} / \mathrm{step}$. The applied velocity progressively induces increase in stress in the soil mass, at a specific point large settlement is caused by no increase in stress; this stress is taken as ultimate bearing capacity.

\subsection{Determination of Model Parameters}

Because the available stress levels in model tests are much smaller than the prototype footings, it is difficult to perform these laboratory tests under such low confining pressure threfore elastic moduli of soils adopted in the present numerical study were directly taken from the pressure-settlement response of plate load tests; this method was adopted by few researchers in the past working in similar areas (Sireesh S 2005; Latha and Somwanshi 2009). Assuming Poisson's ratio of clay to be 0.5 , bulk modulus and shear modulus values were determined. To determine the interface properties between geocell and soil mass, linear model with Mohr-Coulomb yield criterion was adopted. Modified direct shear test 
was used to determine the interface shear strength properties $\left(\boldsymbol{c}_{i}\right.$ and $\left.\phi_{i}\right)$ between geocell and clay. The interface shear modulus value $\left(\boldsymbol{k}_{\boldsymbol{i}}\right)$ was determined from the slope of the shear stress vs. shear displacement curve from the modified direct shear test. List of modal parameters are presented in table 4.

Table 4: Model Parameters selected for numerical studies.

\begin{tabular}{|c|c|}
\hline Clay & Values \\
\hline Young's Modulus $\boldsymbol{E}(\mathrm{MPa})$ & 5 \\
\hline Young's Modulus $\boldsymbol{E}(\mathrm{MPa})$ & 0.3 \\
\hline Poisson's ratio, $\boldsymbol{\mu}$ & 3.3 \\
\hline Bulk Modulus, $\boldsymbol{K}(\mathrm{MPa})$ & 2 \\
\hline Shear Modulus, $\boldsymbol{G}(\mathrm{MPa})$ & 37.5 \\
\hline Friction angle $\boldsymbol{\phi}(\mathrm{deg})$ & 25 \\
\hline Dilation angle, $\boldsymbol{\psi}(\mathrm{deg})$ & 1 \\
\hline Cohesion, $\boldsymbol{c}(\mathrm{kPa})$ & 16.4 \\
\hline Unit weight, $\boldsymbol{\Gamma}\left(\mathrm{kN} / \mathrm{m}^{3}\right)$ & \\
\hline Geocell & Values \\
\hline Young's Modulus $\boldsymbol{E}(\mathrm{MPa})$ & 275 \\
\hline Poisson's ratio, $\boldsymbol{\mu}$ & 0.2 \\
\hline Interface shear modulus, $\boldsymbol{k}_{\boldsymbol{i}}(\mathrm{MPa} / \mathrm{m})$ & 5 \\
\hline Interface cohesion, $\boldsymbol{c}_{\boldsymbol{i}}(\mathrm{kPa})$ & 0 \\
\hline Interface friction angle, $\boldsymbol{\phi}_{\boldsymbol{i}}(\mathrm{deg})$ & 32 \\
\hline Thickness, $\boldsymbol{t}_{\boldsymbol{i}}(\mathrm{mm})$ & 1.52 \\
\hline
\end{tabular}

\subsection{Validation of Numerical Model}

For finite element modeling in FLAC 3D, fineness of the selected mesh and applied velocity play very important role illustrated in study of Frydman and Burd [7]. They observed that fine mesh with small velocity gave better and reasonable results for bearing capacity calculation.

To confirm that boundary conditions are within permissible limits, preliminary analysis were carried out after which sensitivity analysis was done to select the optimum mesh size of the model. Before carrying out the simulations onto the reinforced bed, un-reinforced model was validated with Boussinesq's theory. To this end, uniform pressure was applied at the center of the model and corresponding stress was measured on vertical and horizontal plane, these values were compared with that of Boussinesq's theory. Values from FLAC 3D and Boussinesq's theory were in good agreement.

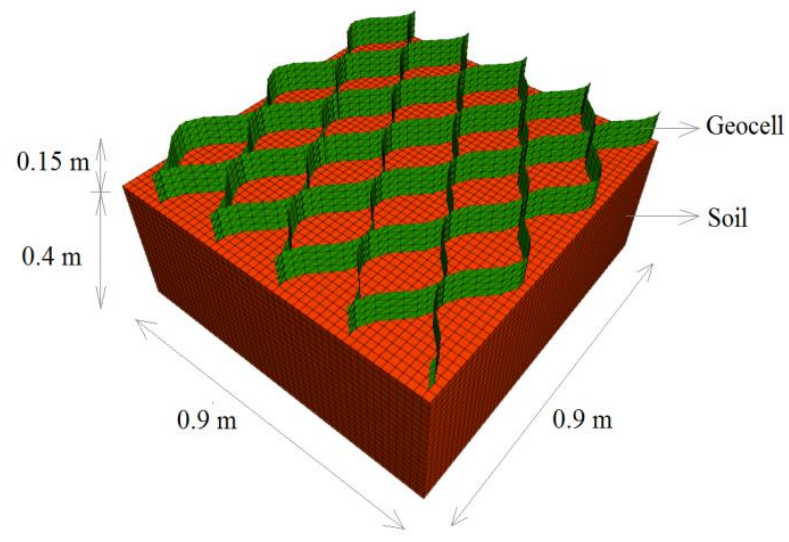

(a)

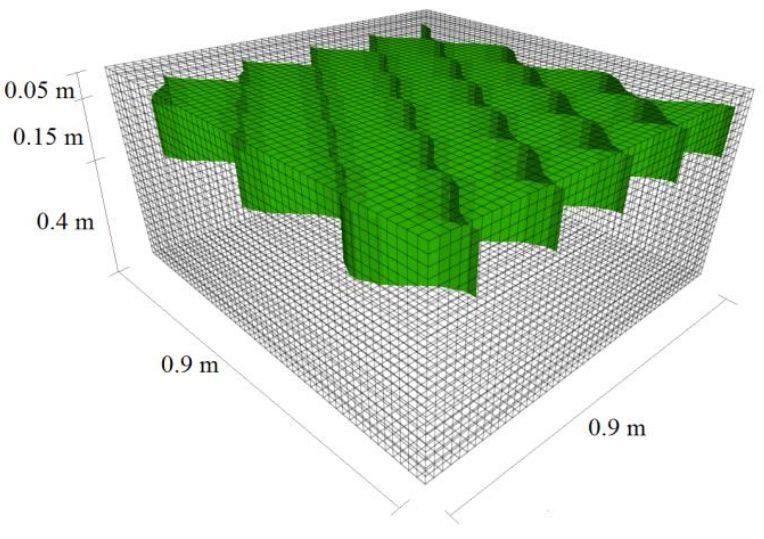

(b)

Fig. 4: a-b Numerical model showing Geocell (a) without infill (b) with fill. 


\subsection{Numerical Results}

Comparison of results between experimental and numerical method has been presented in fig. 7 Good agreement between experimental and numerical data was observed. It was observed that, as the spacing between the footings increases effect of interference reduces, and eventually at certain spacing, here in this study when $\mathrm{S} / \mathrm{B}=2$, there is no longer interference between the adjacent footings and thus each act as an individual isolated footing which can is shown in fig. 3a and $3 \mathrm{~b}$. When spacing between the footings was $0.5 \mathrm{~B}$ maximum effect of interference was observed. When the footings are placed close to each other, region between the footings becomes stiffer before soil fails; this is explained as increase in confinement between the footings that reduces as the spacing between the footings is increased. Larger magnitude of displacement vectors are observed towards the edge of the footings compared to that towards the center of the footings when footings are 2B distance apart from each other, the values of displacement vectors approaches to that of isolated footings.

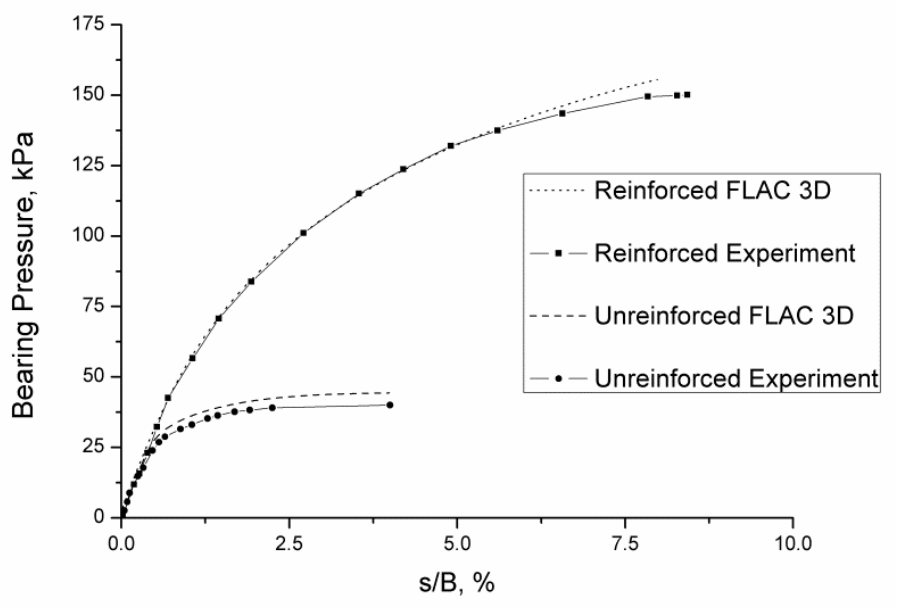

Fig. 7: Bearing pressure v/s settlement-ratio Numerical and experimental results [Isolated footing].

\section{Conclusion}

Following conclusions are drawn from the discussion

- From series of model plate load test experiment it is concluded that there exists interference effect between closely spaced footings on clay that reduces with increase in clear spacing between the footings.

- Maximum interference factor $\boldsymbol{I}_{\boldsymbol{F}-\boldsymbol{U} \boldsymbol{n} r}$ of 1.35 was observed when the spacing between footings was $0.5 \mathrm{~B}$. that reduced with increase in spacing.

- Significant improvement of bearing capacity up to 3 times was observed when geocell was used. Interference factor, $\boldsymbol{I}_{\boldsymbol{F} \text {-Geocell }}$ of 1.20 was observed in case of geocell reinforced clay.

- Numerical model analysis in FLAC 3D were run considering rough footing rested on soil medium characterized by Mohr-Coulomb criterion and concluded that $\boldsymbol{I}_{F}$ depends on the spacing between the footing.

\section{References}

[1] J. Kumar, and M. K. Bhoi, "Interference of two closely spaced strip footings on sand using model tests," Journal of Geotechnical and Geoenvironmental Engineering, ASCE, vol. 135, no. 4, pp. 595-604, 2009.

[2] M. Ghazavi, A. A. Lavasan, "Interference effect of shallow foundations constructed on sand reinforced with geosynthetics," Geotext Geomembranes, vol. 26, no. 5, pp. 404-15, 2008.

[3] V. A. Guido, D. K. Chang, and M. A. Sweeny, "Comparison of geogrid and geotextile reinforced earth slabs," Canadian Geotechnical Journal, vol. 23, pp. 435-440, 1986.

[4] M. T. Omar, B. M. Das, V. K. Puri and S. C. Yen, "Ultimate bearing capacity of shallow foundation on sand with geogrid reinforcement," Canadian Geotechnical Journal, vol. 30, pp. 545-549, 1993. 
[5] Itasca, Fast Lagrangian Analysis of Continua (FLAC3D 4.00). Itasca Consulting Group Inc, Minneapolis, USA, 2008.

[6] E. T. Selig, and K. E. McKee, "Static and dynamic behaviour of small footings," Journal of Solid Mechanics and Foundation, Division, ASCE, vol. 87, pp. 29-47, 1961.

[7] S. Frydman, H. J. Burd, "Numerical studies of bearing capacity factor Nc," J Geotech Geoenviron Eng ASCE, vol. 123, no. 1, pp. 20-9, 1997. 